\title{
Revision of Newsteadia (Homoptera: Coccoidea) of the Nearctic and Neotropic Regions, with Descriptions of New Species
}

\author{
F. KOZÁR and ZSUZSANNA KONCZNÉ BENEDICTY \\ Plant Protection Institute, Hungarian Academy of Sciences, \\ H-1525 Budapest, Pf. 102, Hungary
}

\begin{abstract}
Six new species of Newsteadia are described from the Nearctic and Neotropic Regions. A key is presented for the identification of 10 species currently included in the genus from these regions. The number of species in the genus worldwide is 37. A modified concept of the genus is presented and some new characters are given as diagnostic of the genus. The zoogeography of the genus is discussed. new species.

Keywords: Homoptera, Coccoidea, Ortheziidae, Newsteadia, Nearctic and Neotropic Regions,
\end{abstract}

The genus Newsteadia was studied in detail by Morrison (1925, 1952). Since 1952 one new species (N. trisegmentalis) was described from the Nearctic Region (USA, Ga) by Howell (1975). Only one species, N. tristani (Morrison, 1952) was recorded from the Neotropic Region (Costa Rica, and Mexico). New distribution records in the Eastern USA, of the two known species ( $N$. americana, and $N$. minima) are given in the work of Kosztarab (1996). There are no records of this genus in the western part of USA (Morrison, 1952; Gill, 1993; Miller et al., 1999).

The purpose of the present work is to provide a revision of the genus Newsteadia in the Nearctic and Neotropic Regions, including descriptions of some new species.

\section{Materials and Methods}

The insects described in this study were collected mostly using a Berlese funnel and are from the Hungarian collecting expeditions of soil arthropods (more than 1000 samples), from 12 countries (Chile, Cuba, Santa Lucia, Brazil, Mexico, Falkland Islands, Ecuador, Paraguay, Costa Rica, Bolivia, Peru, Venezuela) (Dr. János Balogh, Collection of Arachnida, University of Loránd Eötvös (ELTE), Dr. Sándor Mahunka, Collection of Arachnida, Hungarian Natural History Museum, Budapest, Hungary) (HNHM). The collection numbers in the text are from the collection of Dr. J. Balogh and Dr. S. Mahunka. In these samples 168 contained specimens of Ortheziidae, among them 39 samples contained Newsteadia species, 121 specimens of Mixorthezia, 8 specimens of Orthezia, and none of Nipponorthezia. The specimens of previously described species are in the collection of the US National Collection of Insects, Beltsville, Maryland, USA (USNM), and University of Napoli (Portici). 
The insects studied were mounted on microscope slides, or partly preserved in alcohol. The holotypes of new species are deposited in the Hungarian Natural History Museum, Budapest (HNHM). Paratypes are deposited in the Plant Protection Institute, Hungarian Academy of Science (PPI), and in the collection of USNM (Beltsville, USA).

Terminology follows that of Morrison (1925, 1952), and of Miller and Kozár (1999, in preparation) except for some new characters found in the present work.

\section{Results}

Newsteadia americana Morrison, 1925

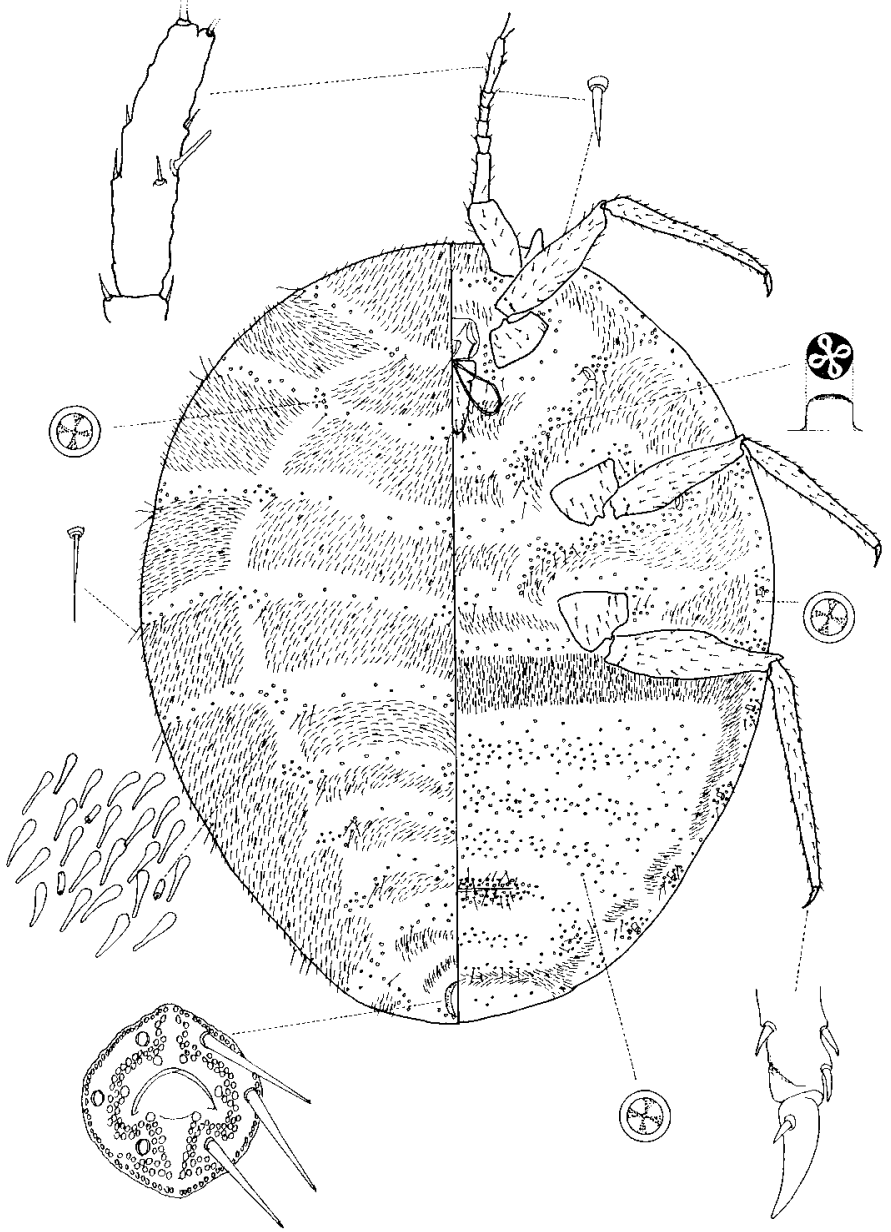

Fig. 1. N. americana Morrison, 1925, female 


\section{MATERIAL EXAMINED}

Holotype: female, USA, Maryland, 08. 08, 1917, Leg: H. S. Barber, on the same slide one paratype. Two paratype females on one slide, USA, Virginia shore, opp. Plummers Is, Md, June 15, 1922, Leg: H. Morrison. One paratype female, Canada, Ontario, Grimsby, Leg. Horn.

The species is different from all species known in the Region by densely covered body with wax plates including the venter of the thorax. A new drawing is presented (Fig. 1), because the original drawing does not contain several important characters, like the number of quadrilocular pores on the venter of abdomen and other parts of the body.

This species was not found in our samples.

\section{Newsteadia borhidii sp. $\mathrm{n}$.}

\section{MATERIAL EXAMINED}

Holotype: female, Cuba, Havana, 16. 02. 1989, Leg: F. Mészáros, No 238. Paratype: two females on one slide, Cuba Sierra Esperon, Leg: A. Borhidi, No. 243, and 1 female, Brazil, Fazenda Aqua Azul, 1967, Leg: J. Balogh, No. B 24.

\section{DESCRIPTION OF ADULT FEMALE}

Mounted specimen (Fig. 2): Holotype adult female $1.2 \mathrm{~mm}$ long, $0.8 \mathrm{~mm}$ wide. Antennae 3-segemented, 1st segment $186 \mu \mathrm{m}$ long, 2nd segment $102 \mu \mathrm{m}$ long, apical segment $390 \mu \mathrm{m}$ long, all segments with clavate setae, the longest is $47 \mu \mathrm{m}$ long, with 9 setae on apical segment, apical seta $114 \mu \mathrm{m}$ long, without subapical seta, medial sensory seta $34 \mu \mathrm{m}$ long situated near end of segment.

\section{VENTER}

Labium $166 \mu \mathrm{m}$ long, partly with clavate setae. Stylet loop as long as labium. Legs: 1 st coxa $90 \mu \mathrm{m}$ long, trochanter-femur 320, tibia-tarsus $432 \mu \mathrm{m}$ long, claw 42, claw digitules destroyed, 2nd coxa $94 \mu \mathrm{m}$ long, trochanter-femur 390, tibia-tarsus 457, claw 41, claw digitules destroyed, 3rd coxa $98 \mu \mathrm{m}$ long, trochanter-femur 415, tibia-tarsus 498 $\mu \mathrm{m}$ long, claw 43, claw digitules $7 \mu \mathrm{m}$ long, with clavate setae from coxae to middle of tibia-tarsus and with spinelike setae on posterior part of tibia-tarsus; without flagellate sensory setae near tibial sensorium on all legs; trochanter with 4 sensory pores on each surface. Ovisac band short, not interrupted in middle, with a special depression covered by quadrilocular pores in front of middle part of ovisac, ovisac wax plate groups on last segments of abdomen absent; wax plates almost absent on the thorax and head. Coxal depressions not developed. Anterior thoracic spiracles without quadrilocular pores, anterior thoracic spiracles $26 \mu \mathrm{m}$ in diameter. Hairlike setae scattered in medial areas of thorax. Quadrilocular and simple pores 4-7 $\mu \mathrm{m}$ in diameter; tubular quadrilocular pores long, protruding from derm, associated with wax plates; quadriloculars and simple pores present in wide bands within ovisac band and in groups between wax plates elsewhere. Abdominal spiracles five pairs. 


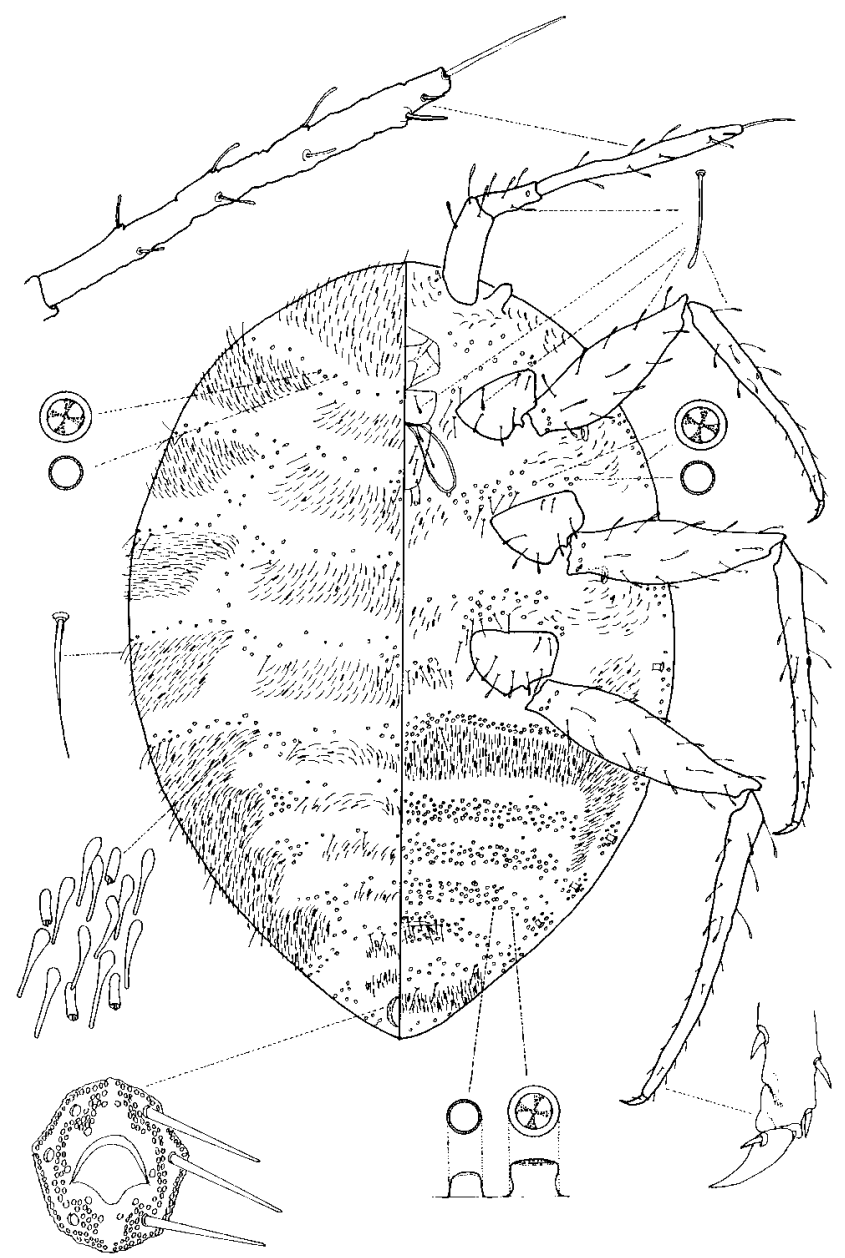

Fig. 2. N. borhidii sp. n., female

\section{DORSUM}

Wax plates cover only part of surface. Spines at margin of wax plates elongate, $18 \mu \mathrm{m}$ long. Hairlike setae present in marginal clusters near posterior edges of marginal wax plates, and near anterolateral and anteromedial edge of each dorsomedial wax plate, $37 \mu \mathrm{m}$ long. Quadrilocular and discoidal pores scattered between wax plates, $8 \mu \mathrm{m}$ long tubular ducts present. Anal ring with rows of pores; longest anal ring seta $42 \mu \mathrm{m}$ long, anal ring $48 \mu \mathrm{m}$ wide and $65 \mu \mathrm{m}$ long.

The species is named after the collector Dr. Attila Borhidi, Hungarian botanist, who worked for many years in Cuba and collected several interesting scale insect species in different parts of the world. 


\section{COMMENTS}

$N$. borhidii is similar to $N$. tristani, but differs by having clavate setae on all segments of the antennae, and by the presence of long tubular ducts.

Newsteadia brasiliensis sp. $\mathrm{n}$.

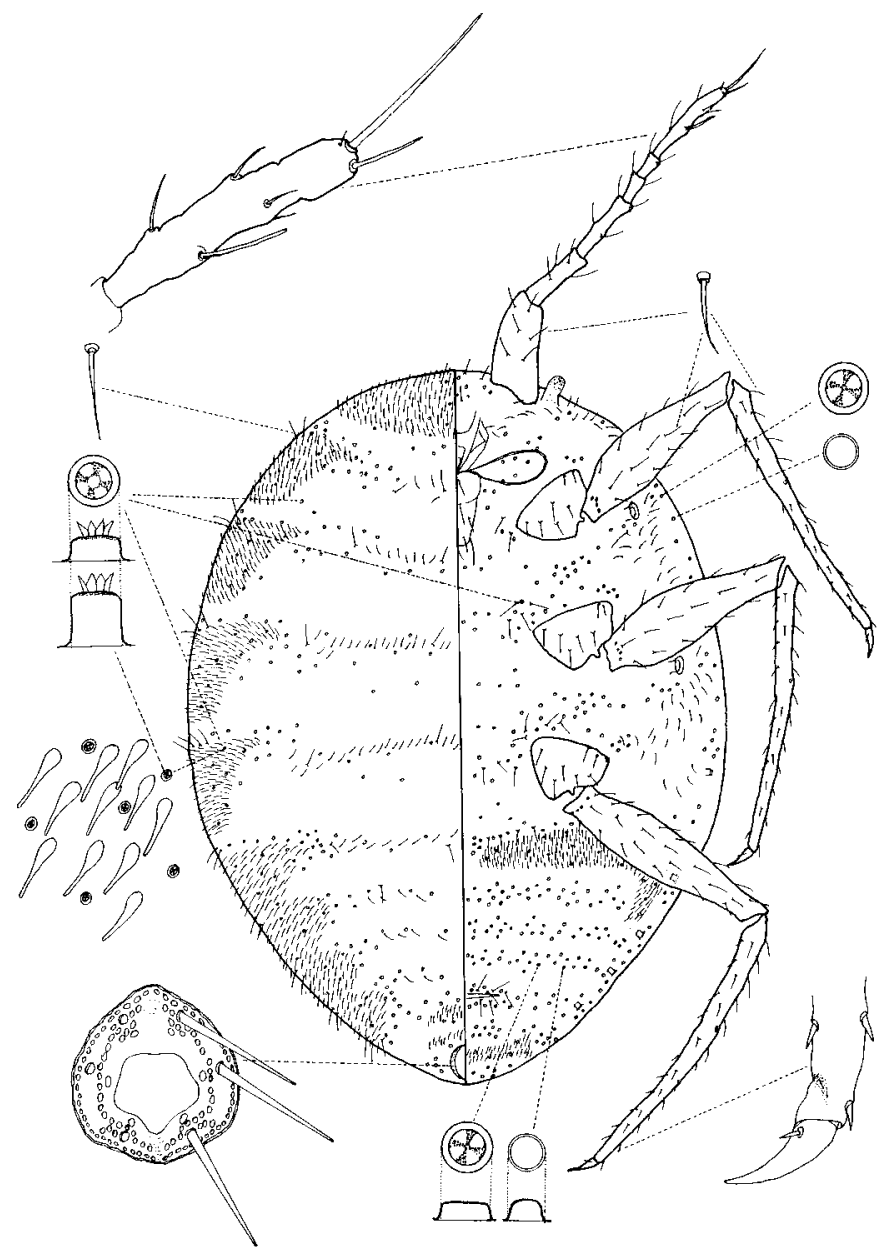

Fig. 3. N. brasiliensis sp. n., female

\section{MATERIAL EXAMINED}

Holotype: female, Brazil (1550 m a.s.1.), 1995, Leg: J. Balogh, No. B 2. Paratypes: one female from the same collection as the holotype. 


\section{DESCRIPTION OF ADULT FEMALE}

Mounted specimen (Fig. 3): Holotype adult female $1.0 \mathrm{~mm}$ long, $0.8 \mathrm{~mm}$ wide. Antennae 6-segmented, 1st segment $186 \mu \mathrm{m}$ long, 2nd segment $122 \mu \mathrm{m}$ long, apical segment $141 \mu \mathrm{m}$ long, with $24 \mu \mathrm{m}$ long, strong hairlike setae, with 7 setae on apical segment, apical seta $94 \mu \mathrm{m}$ long, with one, $34 \mu \mathrm{m}$ long subapical seta, medial sensory seta $42 \mu \mathrm{m}$.

\section{VENTER}

Labium $110 \mu \mathrm{m}$ long. Stylet loop as long as labium. Legs: 1st coxa $77 \mu \mathrm{m}$ long, trochanter-femur 320, tibia-tarsus $440 \mu \mathrm{m}$ long, claw36, claw digitules $7 \mu \mathrm{m}$ long, 2nd coxa $84 \mu \mathrm{m}$ long, trochanter-femur 326, tibia-tarsus 465, claw 37, claw digitules $7 \mu \mathrm{m}$ long, 3rd coxa $96 \mu \mathrm{m}$ long, trochanter-femur 352, tibia-tarsus $498 \mu \mathrm{m}$ long, claw 40, claw digitules $7 \mu \mathrm{m}$ long, partly with strong hairlike, and spinelike setae; flagellate sensory setae near tibial sensorium absent on all legs; trochanter with 4 sensory pores on each surface. Ovisac band interrupted in middle, short, ovisac wax plate groups on last segments of abdomen absent; wax plates nearly absent on thorax and head. Coxal depressions not developed. Anterior thoracic spiracles with some associated quadrilocular and simple pores, 3-5 $\mu \mathrm{m}$ in diameter, anterior thoracic spiracles $20 \mu \mathrm{m}$ in diameter. Hairlike setae, scattered in medial areas of thorax. Quadrilocular and simple pores 3-6 $\mu \mathrm{m}$ in diameter; quadriloculars and simple pores present in wide, long bands within ovisac band and scattered between wax plates elsewhere. Abdominal spiracles five pairs.

\section{DORSUM}

Wax plates scattered in single rows. Spines at margin of wax plate elongate 13 $\mu \mathrm{m}$ long. Hairlike setae present in marginal clusters near posterior edges of marginal wax plates, and near anterolateral and anteromedial edge of each dorsomedial wax plate, 19 $\mu \mathrm{m}$ long. Short tubular quadrilocular pores scattered between wax plates, long tubular ducts absent. Anal ring with two rows of pores; longest anal ring seta $36 \mu \mathrm{m}$ long, anal ring round, $46 \mu \mathrm{m}$ in diameter.

The species is named after the country of collection of the samples.

\section{COMMENTS}

$N$. brasiliensis is different from other Newsteadia species, by having 6-segmented antennae with long, strong, setose hairlike setae on the antennae.

Newsteadia costaricaensis sp. $\mathrm{n}$.

\section{MATERIAL EXAMINED}

Holotype: female, Costa Rica, Sierra de la Muerte, El Empalme (2150 m a.s.l.), 1992, Leg: J. Balogh, No. B 62. Paratypes: Five females from the same collection as the holotype, on 5 slides, Nos. B 61, B 62. 


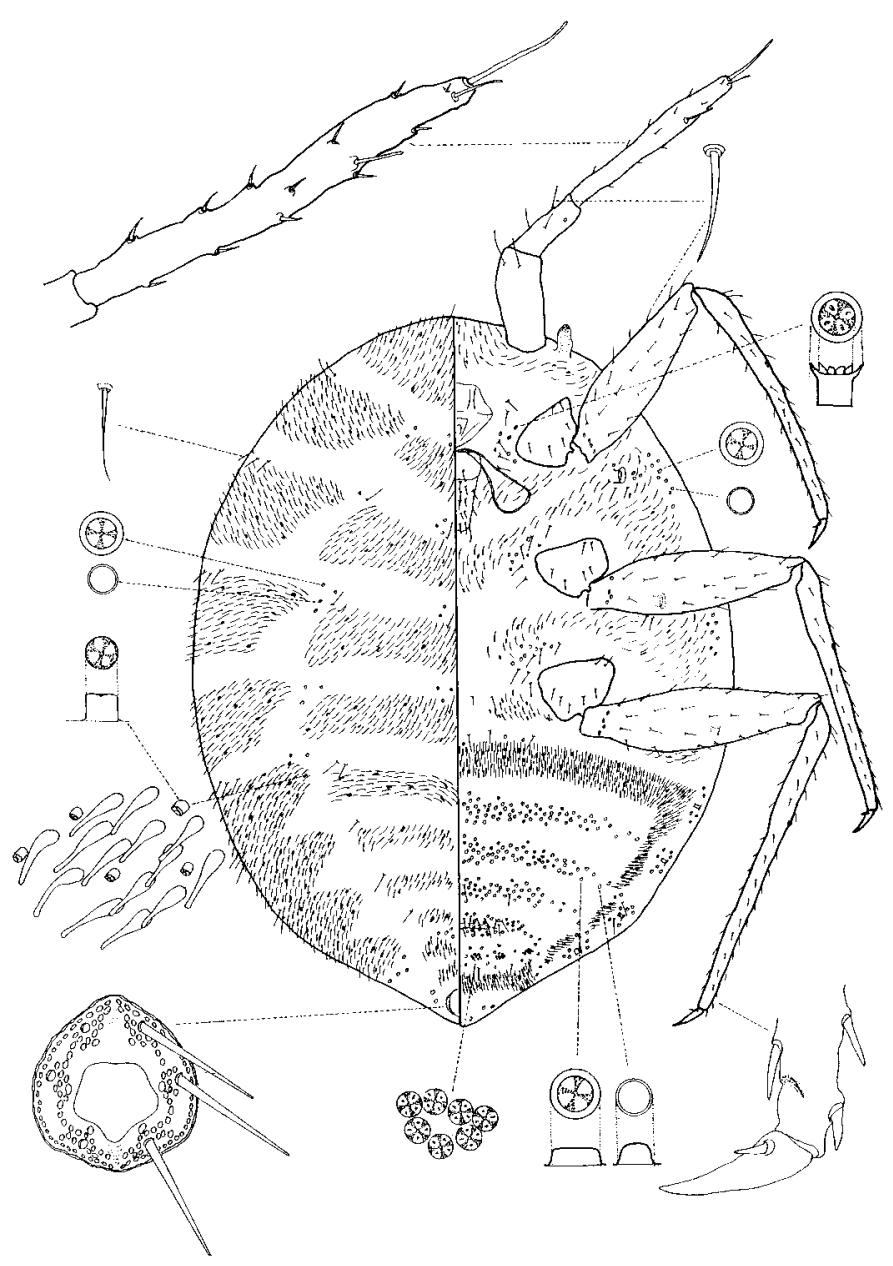

Fig. 4. N. costaricaensis sp. n., female

\section{DESCRIPTION OF ADULT FEMALE}

Mounted specimen (Fig. 4): Holotype adult female $1.2 \mathrm{~mm}$ long, $1.0 \mathrm{~mm}$ wide. Antennae 3-segemented, 1st segment $176 \mu \mathrm{m}$ long, 2nd segment $128 \mu \mathrm{m}$ long, apical segment $336 \mu \mathrm{m}$ long, basal segments of antennae with strong hairlike setae, apical segment with 15 setose hairlike setae, apical seta $84 \mu \mathrm{m}$ long, with $34 \mu \mathrm{m}$ long subapical seta, with a microseta at base, medial sensory seta $35 \mu \mathrm{m}$.

\section{VENTER}

Labium $208 \mu \mathrm{m}$ long. Stylet loop as long as labium. Legs: 1st coxa $121 \mu \mathrm{m}$ long, trochanter-femur 332, tibia-tarsus $457 \mu \mathrm{m}$ long, claw 38, claw digitules $9 \mu \mathrm{m}$ long, 2nd 
coxa $128 \mu$ m long, trochanter-femur 357, tibia-tarsus 473, claw 38, claw digitules $9 \mu \mathrm{m}$ long, 3rd coxa $144 \mu \mathrm{m}$ long, trochanter-femur 398, tibia-tarsus $540 \mu \mathrm{m}$ long, claw 43, claw digitules $10 \mu \mathrm{m}$ long, with spinelike setae; without flagellate sensory setae near tibial sensorium on all legs; trochanter with 4 sensory pores on each surface. Ovisac band complete; wax plates partly cover thorax and head. Coxal depressions not developed. Base of coxa with hairlike setae, quadrilocular pores and some thick-walled $7 \mu \mathrm{m}$ long quadrilocular pores. Anterior thoracic spiracles with some quadrilocular and discoidal pores, 3-5 $\mu \mathrm{m}$ in diameter, anterior thoracic spiracles $20 \mu \mathrm{m}$ in diameter. Quadrilocular and simple pores 4-6 $\mu \mathrm{m}$ in diameter on abdomen; tubular quadrilocular pores short, protruding from derm, associated with wax plates; quadriloculars and simple pores present in wide bands within ovisac band and scattered between wax plates elsewhere. Raw of grouped quadrilocular pores present posterior of vulva, $4 \mu \mathrm{m}$ in diameter. Abdominal spiracles five pairs.

\section{DORSUM}

Wax plates cover most surface. Spines at margin of wax plate elongate $17 \mu \mathrm{m}$ long. Hairlike setae present in small numbers near posterior edges of marginal wax plates, and near anterolateral and anteromedial edge of each dorsomedial wax plate, $26 \mu \mathrm{m}$ long. Tubular-like quadrilocular and discoidal pores scattered between wax plates. In wax plates short tubular ducts $4 \mu \mathrm{m}$ long present, long tubular ducts absent. Anal ring with rows of pores; longest anal ring seta $41 \mu \mathrm{m}$ long, anal ring $48 \mu \mathrm{m}$ wide and $49 \mu \mathrm{m}$ long.

The species is named after the country of collection.

\section{COMMENTS}

$N$. costaricaensis is similar to $N$. trisegmentalis, but differs by having clusters of quadrilocular pores on the venter of the abdomen, by the presence of a subapical seta, and by the absence of long tubular ducts.

\section{Newsteadia floridensis sp. $\mathrm{n}$.}

\section{MATERIAL EXAMINED}

Holotype: female, USA, Florida, Ocala Nat. For. 26.11.72, Marion Co., Leg: R. D. Kaplan. Paratype: one female from the same collection as the holotype. Types are deposited in the collection of USNM.

\section{DESCRIPTION OF ADULT FEMALE}

Mounted specimen (Fig. 5): Holotype adult female $1.0 \mathrm{~mm}$ long, $0.8 \mathrm{~mm}$ wide. Antennae 7-segmented, 1st segment $144 \mu \mathrm{m}$ long, 2nd segment $102 \mu \mathrm{m}$ long, apical segment $147 \mu \mathrm{m}$ long, with clavate setae on the first two segments, with spinelike setae on other segments, apical seta $70 \mu \mathrm{m}$ long, subapical seta $22 \mu \mathrm{m}$ long, medial sensory seta $24 \mu \mathrm{m}$.

\section{VENTER}

Labium $157 \mu \mathrm{m}$ long. Stylet loop as long as labium. Legs: 1st coxa $96 \mu \mathrm{m}$ long, trochanter-femur 262, tibia-tarsus $398 \mu \mathrm{m}$ long, claw 35, claw digitules $8 \mu \mathrm{m}$ long, 2nd 


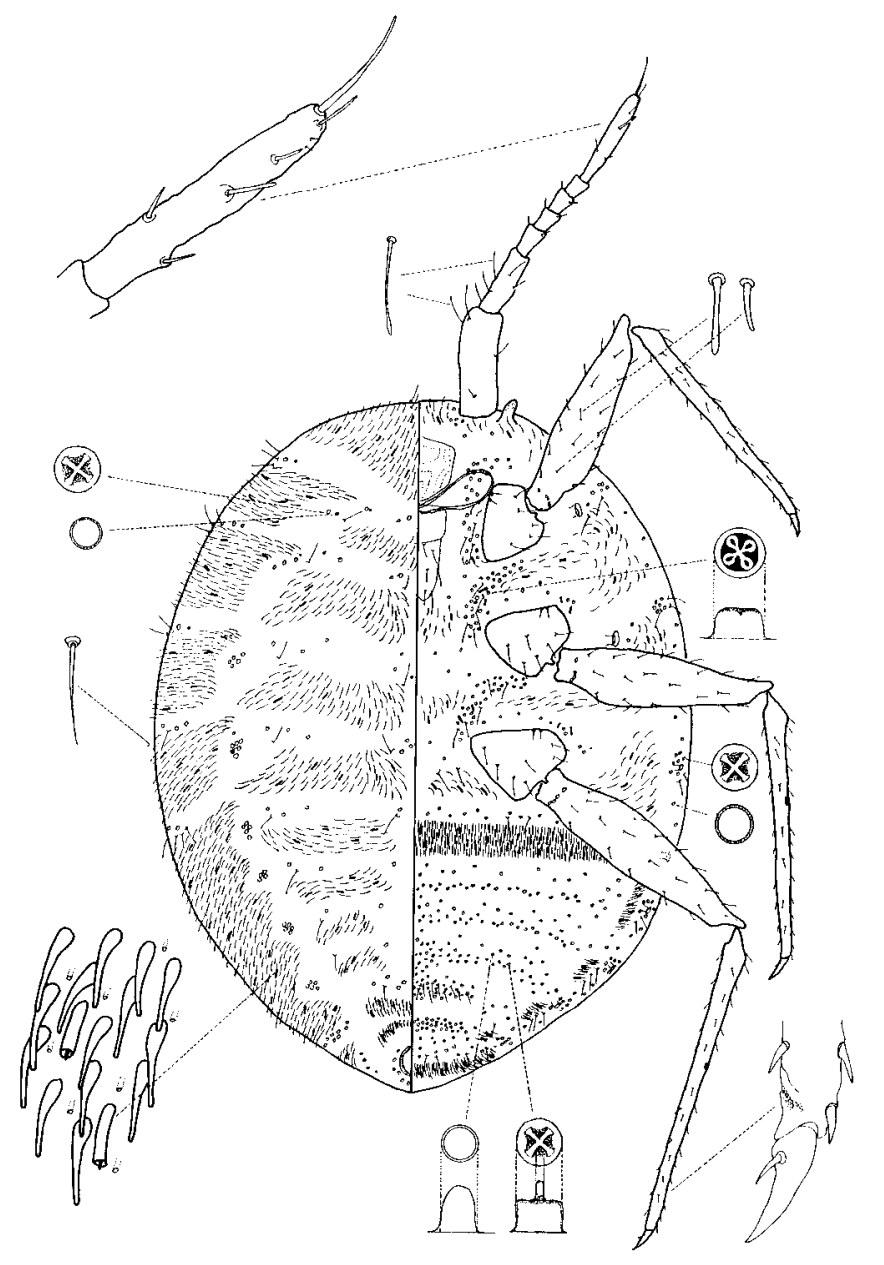

Fig. 5. N. floridensis sp. n., female

coxa $103 \mu \mathrm{m}$ long, trochanter-femur 294, tibia-tarsus 415, claw 36, claw digitules $9 \mu \mathrm{m}$ long, 3rd coxa $110 \mu \mathrm{m}$ long, trochanter-femur 336, tibia-tarsus $465 \mu \mathrm{m}$ long, claw 36, claw digitules $9 \mu \mathrm{m}$ long, partly with clavate, and with spinelike setae; without flagellate sensory setae near tibial sensorium on all legs; trochanter with 4 sensory pores on each surface. Ovisac band not interrupted in the middle, ovisac wax plate groups on last segments of abdomen present; wax plates in small groups on thorax and head. Coxal depressions with groups of quadrilocular pores, hairlike setae and tubular ducts. Anterior thoracic spiracles with some quadrilocular pores, $6 \mu \mathrm{m}$ in diameter, anterior thoracic spiracles $23 \mu \mathrm{m}$ in diameter. Hairlike setae scattered in medial areas of thorax. Quadrilocular and simple pores 3-5 $\mu \mathrm{m}$ in diameter; tubular quadrilocular pores long, 
protruding from derm, associated with wax plates club-shaped pores are present, quadriloculars and simple pores present in rows within ovisac band and scattered between wax plates elsewhere. Abdominal spiracles five pairs.

\section{DORSUM}

Wax plates interrupted in middle of bands, cover the surface. Spines at margin of wax plate elongate $17 \mu \mathrm{m}$ long. Hairlike setae present in marginal clusters near posterior edges of marginal wax plates, and near anterolateral and anteromedial edge of each dorsomedial wax plate, $23 \mu \mathrm{m}$ long. Microtubular ducts scattered, abundant between wax plates, long tubular ducts $14 \mu \mathrm{m}$ long. Anal ring with two rows of pores; longest anal ring seta $24 \mu \mathrm{m}$ long, anal ring $48 \mu \mathrm{m}$ in diameter.

The species is named after the state in the USA where it was collected.

\section{COMMENTS}

This specimens were identified as $N$. minima by Morrison, 1952, however $N$. floridensis differs from $N$. minima, by having clavate setae on the first segment of the antenna, and by the presence of groups of quadrilocular pores on the dorsum between the wax plates.

Newsteadia minima Morrison, 1952

\section{MATERIAL EXAMINED}

Holotype: female, USA, Durham, N.C. 08. 09. 1944, Leg:. A. S. Pearse, and 3 paratype females from the same collection as the holotype, on three slides.

This species is different from all known species from the Region by widely separated wax plates especially on the abdominal dorsum, and the small number of wax plate seta on the venter of the thorax.

This species was not found in our samples.

\section{COMMENTS}

Both species (N. americana and N. minima) are similar to N. floccosa De Geer, 1778, and N. kanayana Kawai et Takagi, 1971, from the Palaearctic Region (Kozár, 1998; Kozár and Konczné Benedicty, 1999b). However $N$. floccosa differs from both species by having large group of quadrilocular pores near to coxal bases. $N$. kanayana differs from $N$. floccosa, N. americana and N. minima by having wax plates on the dorsum that are, and by having a small number of wax plate setae on the venter of the thorax.

\section{Newsteadia morrisoni $\mathrm{sp} . \mathrm{n}$.}

\section{MATERIAL EXAMINED}

Holotype: female, Costa Rica, Tarbaca (1550 m a.s.l.), 14. 01. 1993, Leg: J. Balogh, No. B 98. Paratypes: Eleven females from the same collection as the holotype on 9 slides, Nos. B 93, B 95, B 96. Seven females, on four slides, Costa Rica, Sierra de la Muerte (1800 m a.s.1.), 24. 01. 1992, Leg: J. Balogh No. B 54, B 55. 


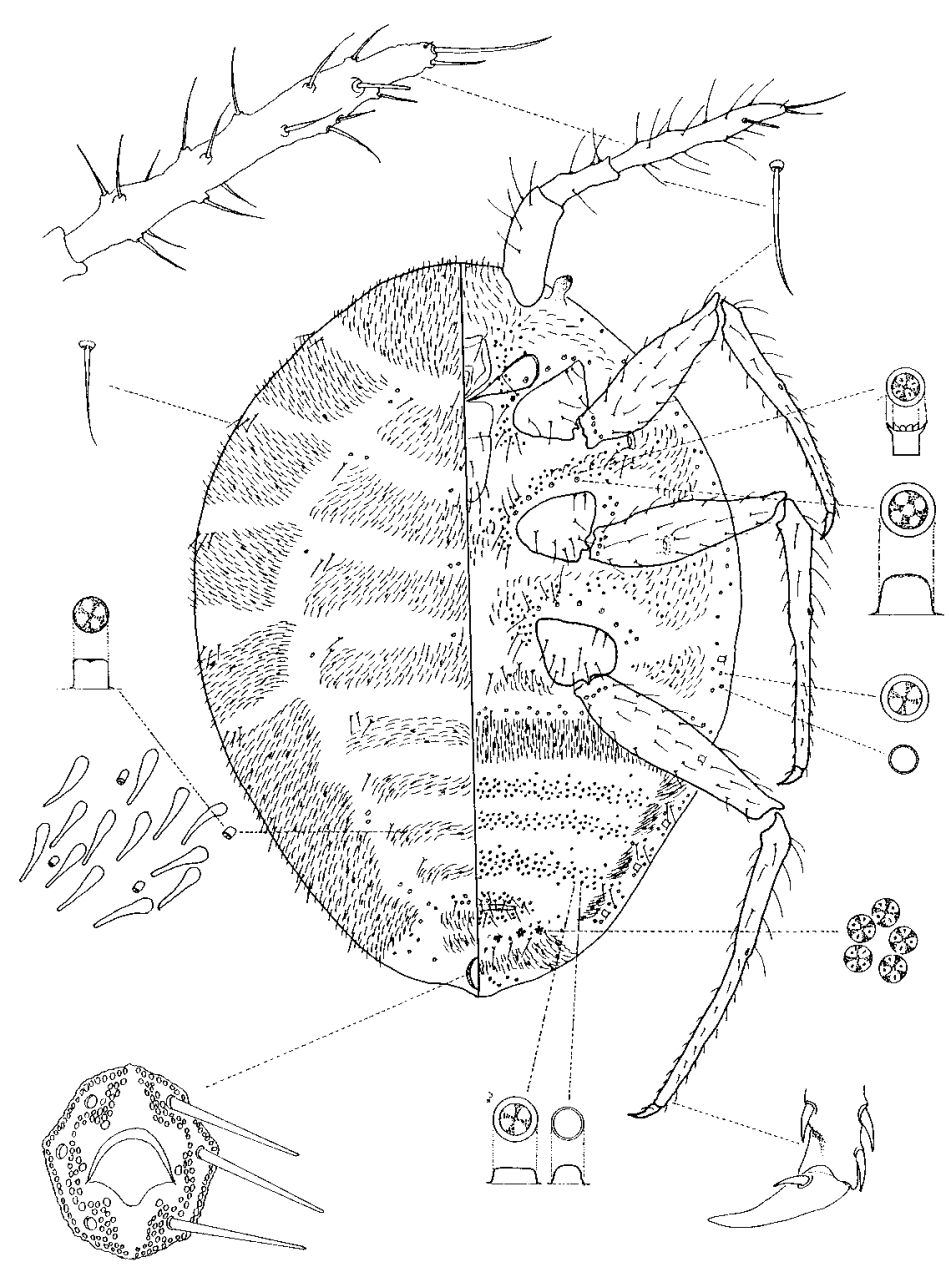

Fig. 6. N. morrisoni sp. n., female

\section{DESCRIPTION OF ADULT FEMALE}

Mounted specimen (Fig. 6): Holotype: adult female $1.3 \mathrm{~mm}$ long, $0.9 \mathrm{~mm}$ wide. Antennae 3-segemented, 1st segment $186 \mu \mathrm{m}$ long, 2nd segment $128 \mu \mathrm{m}$ long, apical segment $314 \mu \mathrm{m}$ long, with long hairlike setae on all segments, with 19 setae on apical segment, apical seta $99 \mu \mathrm{m}$ long, subapical seta $49 \mu \mathrm{m}$ long, with one short subapical seta, medial sensory seta $51 \mu \mathrm{m}$.

\section{VENTER}

Labium $182 \mu \mathrm{m}$ long. Stylet loop as long as labium. Legs: 1st coxa $128 \mu \mathrm{m}$ long, trochanter-femur 332, tibia-tarsus $440 \mu \mathrm{m}$ long, claw 38, claw digitules $8 \mu \mathrm{m}$ long, 2nd 
coxa $131 \mu \mathrm{m}$ long, trochanter-femur 349, tibia-tarsus 473, claw 41, claw digitules $8 \mu \mathrm{m}$ long, 3rd coxa $134 \mu \mathrm{m}$ long, trochanter-femur 382, tibia-tarsus $538 \mu \mathrm{m}$ long, claw 38, claw digitules $10 \mu \mathrm{m}$ long, with hairlike setae on coxae, trochanter-femur, and part of tibiatarsus, and spinelike setae on other parts, of tibia-tarsus and claw; without flagellate sensory setae near tibial sensorium on all legs; trochanter with 4 sensory pores on each surface. Ovisac band complete; wax plates in groups or bands on thorax and head. Coxal depressions not developed. Anterior thoracic spiracles with some quadrilocular pores, 5 $\mu \mathrm{m}$ in diameter, anterior thoracic spiracles $22 \mu \mathrm{m}$ in diameter. Hairlike setae, scattered in medial areas of thorax. Quadrilocular pores $6 \mu \mathrm{m}$ in diameter; tubular quadrilocular pores protruding from derm, associated with wax plates; quadriloculars and simple pores present in wide bands within ovisac band and scattered between wax plates elsewhere. Abdominal spiracles five pairs.

\section{DORSUM}

Wax plates cover only part of surface in wide bands. Spines at margin of wax plate elongate $12 \mu \mathrm{m}$ long. Hairlike setae present in marginal clusters near posterior edges of marginal wax plates, and near anterolateral and anteromedial edge of each dorsomedial wax plate, $22 \mu \mathrm{m}$ long. Short tubular quadrilocular pores present, and long tubular ducts absent. On the dorsum only simple, and some quadrilocular pores are present. Anal ring with rows of pores; longest anal ring seta $43 \mu \mathrm{m}$, anal ring $48 \mu \mathrm{m}$ wide and $50 \mu \mathrm{m}$ long.

The species is named after Harold Morrison, the author of the first World monograph of this family.

\section{COMMENTS}

N. morrisoni differs from all other species known from the region by the large number of long hairlike setae on all segments of the antennae.

Newsteadia trisegmentalis Howell, 1975

\section{MATERIAL EXAMINED}

Holotype: female, USA, Echols Co., Georgia, 07. 03. 1973, on Panicum sp., Leg: S. J. Beshaer, and 2 paratype females from the same collection.

Additional material: There is a female from Florida, Weeki Wachee, Hernando Co. 04. 27. 1975, on Quercus, Leg: R. F. Denno, Det. J. A. Davidson and D. R. Miller, No. 2798, and also one female from Mexico, Brownsville, 08. 06. 1987, on orchids and bromeliad debris, Leg: D. Riley, No. 88-06320, all are in USNM collection.

This species (female and larvae) was found in our samples from Venezuela, between Maracay and Caracas, 1973, Leg: J. Balogh, No. Ve 36. There are four larvae in our samples from Antilles, Santa Lucia, 1980, Leg: S. Mahunka, which probably belongs to this species.

\section{COMMENTS}

This species is similar to $N$. tristani, the morphological differences will be discussed under the latter species. 
Newsteadia tristani (Silvestri, 1924)

\section{MATERIAL EXAMINED}

Holotype (on the original slide written "Typus", but according to handwriting it is not sure that it was written by Silvestri) (the original slide contains two specimens, the lectotype designated here, circled by red colour, on the upper left side of the slide) (Fig 7) (preadult female): (including one syntype, also a preadult female on the same slide) Costa Rica, San Jose, 01. 1917, remounted by Zs. Konczné Benedicty, 1 preadult female from alcohol, from the same collection (mounted by Zs. Konczné Benedicty), from the collection of Napoli University, Portici, Italy. The species was described on the base of these preadult females (Morrison, 1925). Later Morrison (1952) found an adult female in

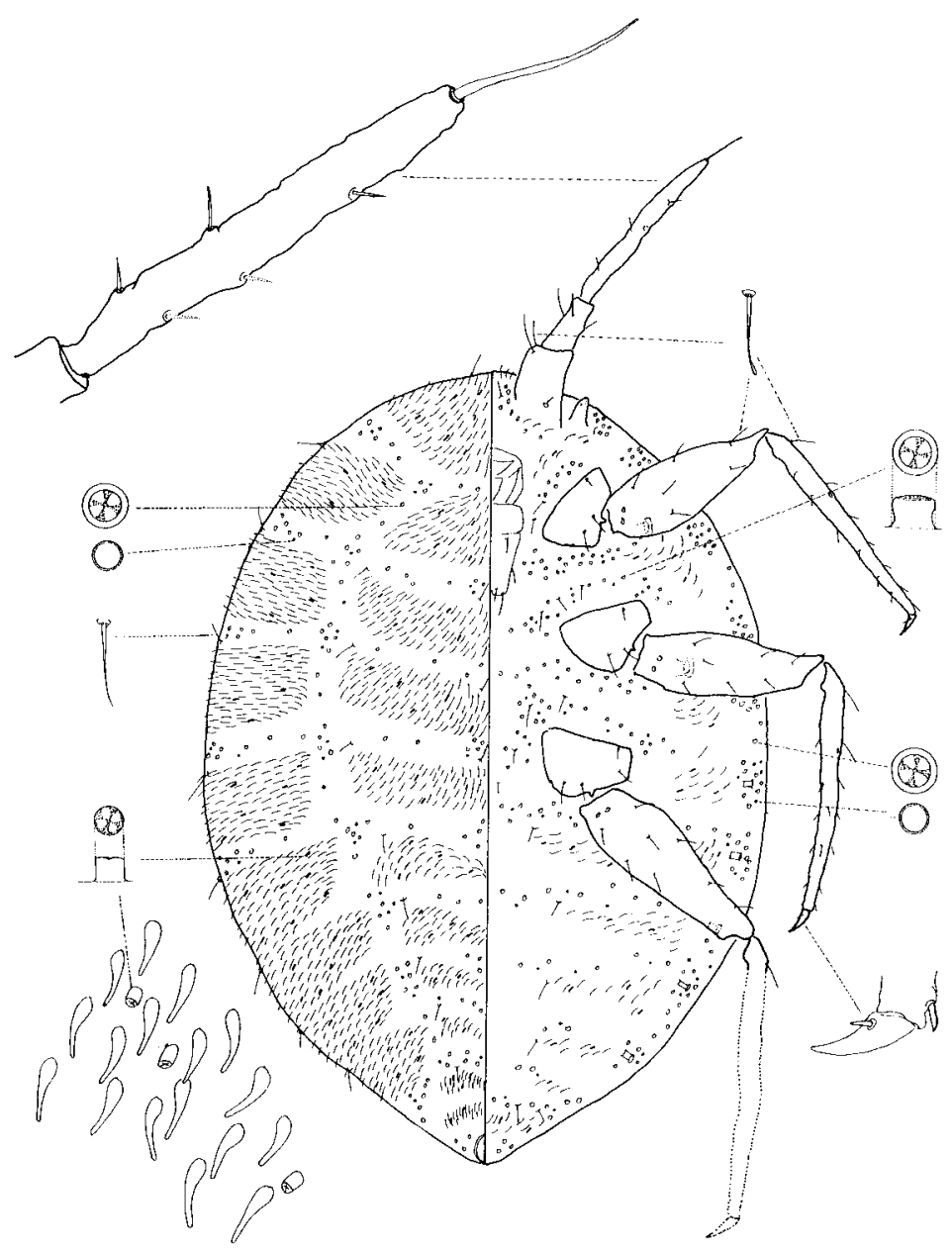

Fig. 7. N. tristani (Silvestri, 1924), preadult female 
his collection from Mexico Tuxtla Gutierrez, 16. 08. 1948, on orchid, Leg: A. Chapman, No. Laredo 47062, which he "accepted as an example of this species".

Here we present a new, detailed drawing, and description of the type material (preadult female) (Fig. 7), drawing, and description (Fig. 8) of the female "example of this species" mentioned by Morrison (1952).

Additional material: The species was found from some other places in our samples. One female, from Mexico, Leg: S. Mahunka, 1996, No. 351. Two females (on two slides) and one female with a larva (on one slide), and 4 larvae (on two slides), from Peru, Iquitos, Lacuna, Quistococha, 01. 12. 1971, Leg: J. Balogh, Nos. B5, B6, B7, B17.

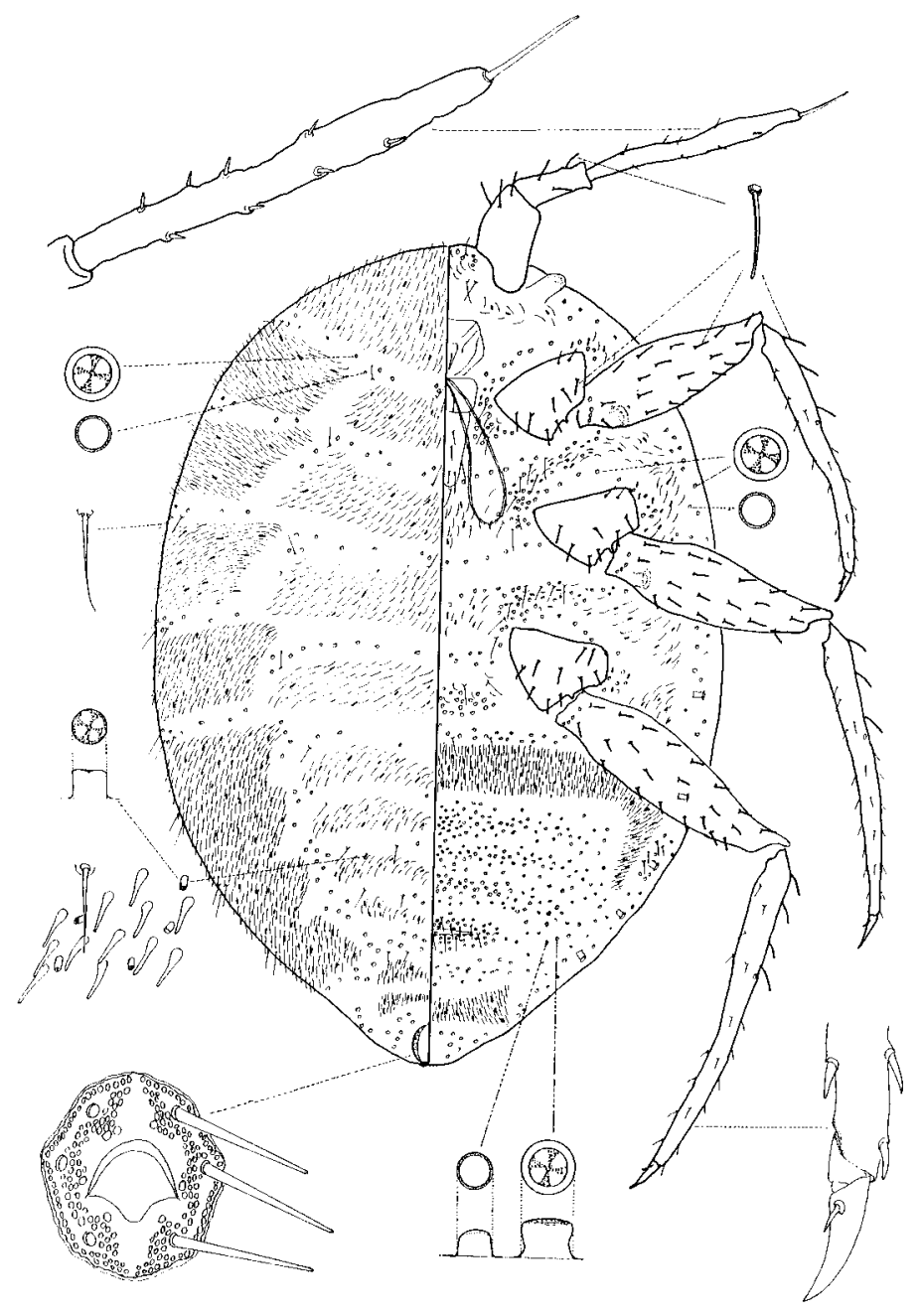

Fig. 8. N. tristani (Silvestri, 1924), female 


\section{DESCRIPTION OF PREADULT FEMALE}

Mounted specimen (Fig. 7): Holotype preadult female $1.3 \mathrm{~mm}$ long, $0.9 \mathrm{~mm}$ wide. Antennae 3-segemented, 1st segment $96 \mu \mathrm{m}$ long, 2nd segment $66 \mu \mathrm{m}$ long, and apical segment $214 \mu \mathrm{m}$ long, with clavate setae on 1st and 2nd segments of the antennae, $30 \mu \mathrm{m}$ long on 1st and 2nd segments, apical seta $82 \mu \mathrm{m}$ long with spinelike setae, without subapical, and medial sensory setae.

\section{VENTER}

Labium $109 \mu \mathrm{m}$ long. Legs: 1st coxa $68 \mu \mathrm{m}$ long, trochanter-femur 208, tibiatarsus $275 \mu \mathrm{m}$ long, claw 30, claw digitules $6 \mu \mathrm{m}$ long, 2nd coxa $72 \mu \mathrm{m}$ long, trochanterfemur 218, tibia-tarsus $282 \mu \mathrm{m}$ long, claw 30, claw digitules $6 \mu \mathrm{m}$ long, 3rd coxa $78 \mu \mathrm{m}$ long, trochanter-femur 243, other parts broken, with clavate setae on coxa, trochanterfemur and part of tibia-tarsus, and with spinelike setae on other part of tibia-tarsus and claw; without flagellate sensory setae near tibial sensorium; trochanter with 2 sensory pores on each surface. Ovisac band absent; wax plates absent, only some wax plate setae present in groups, and rows. Coxal depressions not developed. Anterior thoracic spiracles with associated cluster of quadrilocular and simple pores, 3-6 $\mu \mathrm{m}$ wide, diameter of anterior thoracic spiracles $22 \mu \mathrm{m}$. Hairlike setae few, scattered in medial areas of thorax. Quadrilocular pores $6 \mu \mathrm{m}$ in diameter; present in groups on thorax, and scattered on abdomen. Five pairs of abdominal spiracles.

\section{DORSUM}

Wax plates in wide bands on surface, not divided on midline. Spines at margin of wax plate elongate, with apically rounded apex, $12 \mu \mathrm{m}$ long. Hairlike setae present near posterior edges of marginal wax plates, and near anterolateral and anteromedial edge of each dorsomedial wax plate. Quadrilocular and simple pores scattered between wax plates, 3-5 $\mu \mathrm{m}$ long, short tubular ducts, $4 \mu \mathrm{m}$ long, present in wax plates. Anal ring partly destroyed; longest anal ring seta $22 \mu \mathrm{m}$ long, shorter than length of anal ring; ring $31 \mu \mathrm{m}$ wide, and $34 \mu \mathrm{m}$ long.

\section{COMMENTS}

The preadult female of $N$. tristani is similar to preadult females of $N$. trisegmentalis (not from type series). The most important difference is the presence of a sensory seta on the apical segment of the $N$. trisegmentalis (which is present in all larval and adult stages). This sensory seta is absent in preadult and adult specimens of $N$. tristani. The setae on the first two segments of the antennae, and coxae of $N$. tristani are long and clavate, but short and not clavate in all stages of $N$. trisegmentalis, as was mentioned by Howell (1975), the latter species also has long tubular ducts.

\section{DESCRIPTION OF ADULT FEMALE}

Mounted specimen (Fig. 8): Female (Morrison's “example of this species”) 1.3 $\mathrm{mm}$ long, $0.9 \mathrm{~mm}$ wide. Antennae 3-segmented, 1st segment $128 \mu \mathrm{m}$ long, 2 nd segment 
$102 \mu \mathrm{m}$ long, and apical segment $352 \mu \mathrm{m}$ long, with 3 clavate setae on 1st and 2nd segments, $18-23 \mu \mathrm{m}$ long, with 7 spinelike setae $12 \mu \mathrm{m}$ long on apical segment, apical seta $82 \mu \mathrm{m}$ long, without subapical, and medial sensory seta.

\section{VENTER}

Labium $154 \mu \mathrm{m}$ long. Stylet loop as long as labium. Legs: 1st coxa $102 \mu \mathrm{m}$ long, trochanter-femur 340, tibia-tarsus $423 \mu \mathrm{m}$ long, claw 43, claw digitules $8 \mu \mathrm{m}$ long, 2nd coxa $122 \mu \mathrm{m}$ long, trochanter-femur 365, tibia-tarsus $457 \mu \mathrm{m}$ long, claw 46, claw digitules $8 \mu \mathrm{m}$ long, 3rd coxa $134 \mu \mathrm{m}$ long, trochanter-femur 415, tibia-tarsus $539 \mu \mathrm{m}$ long, claw 48, claw digitules $13 \mu \mathrm{m}$ long, legs with clavate setae on coxae, trochanterfemur and partly on tibia-tarsus, on other part of tibia-tarsus with spinelike setae; without flagellate sensory setae near tibial sensorium; trochanter with 4 sensory pores on each surface. Ovisac band not interrupted, but short, ovisac wax plate groups on last segments of abdomen absent; wax plates very few on the thorax and head. Coxal depressions weakly developed, mesad of each coxa, with a cluster of hairlike setae, wax spines, and many quadrilocular pores. Anterior thoracic spiracles without quadrilocular and simple pores, diameter of anterior thoracic spiracles $35 \mu \mathrm{m}$. Hairlike setae few, scattered in medial areas of thorax. Quadrilocular and discoidal pores 4-6 $\mu \mathrm{m}$ in diameter; quadrilocular and discoidal pores present in wide bands within ovisac band and scattered between wax plates. With five pairs of abdominal spiracles.

\section{DORSUM}

Wax plates in wide bands, partly divided in midline. Spines at margin of wax plate elongate, with apically rounded apex, $16 \mu \mathrm{m}$ long. Hairlike setae present in marginal clusters near posterior edges of marginal wax plates, and near anterolateral and anteromedial edge of each dorsomedial wax plate, $24 \mu \mathrm{m}$ long. Quadrilocular and simple pores scattered between wax plates, 3-5 $\mu \mathrm{m}$ in diameter, tubular ducts short, $4 \mu \mathrm{m}$ long, present in wax plates. Anal ring with rows of pores; longest anal ring seta $38 \mu \mathrm{m}$ long, shorter than length of anal ring; ring $54 \mu \mathrm{m}$ wide, and $60 \mu \mathrm{m}$ long.

\section{COMMENTS}

$N$. tristani (although described only on the basis of preadult females), is a distinct species, distributed in different parts of Central and South America. The new larvae found are nonspecific with the larvae from type series, and the females found altogether with larvae makes possibly to identify this species and accept as valid.

\section{Newsteadia tropicalis $\mathrm{sp} . \mathrm{n}$.}

\section{MATERIAL EXAMINED}

Holotype: female (marked with red circle, on right side of the slide) (including one paratype female on the same slide, Brazil, Leg: J. Balogh, 1995, No. B 76. Paratypes: two females from the same collection as the holotype, on two slides, Nos. B 2, B 76. 


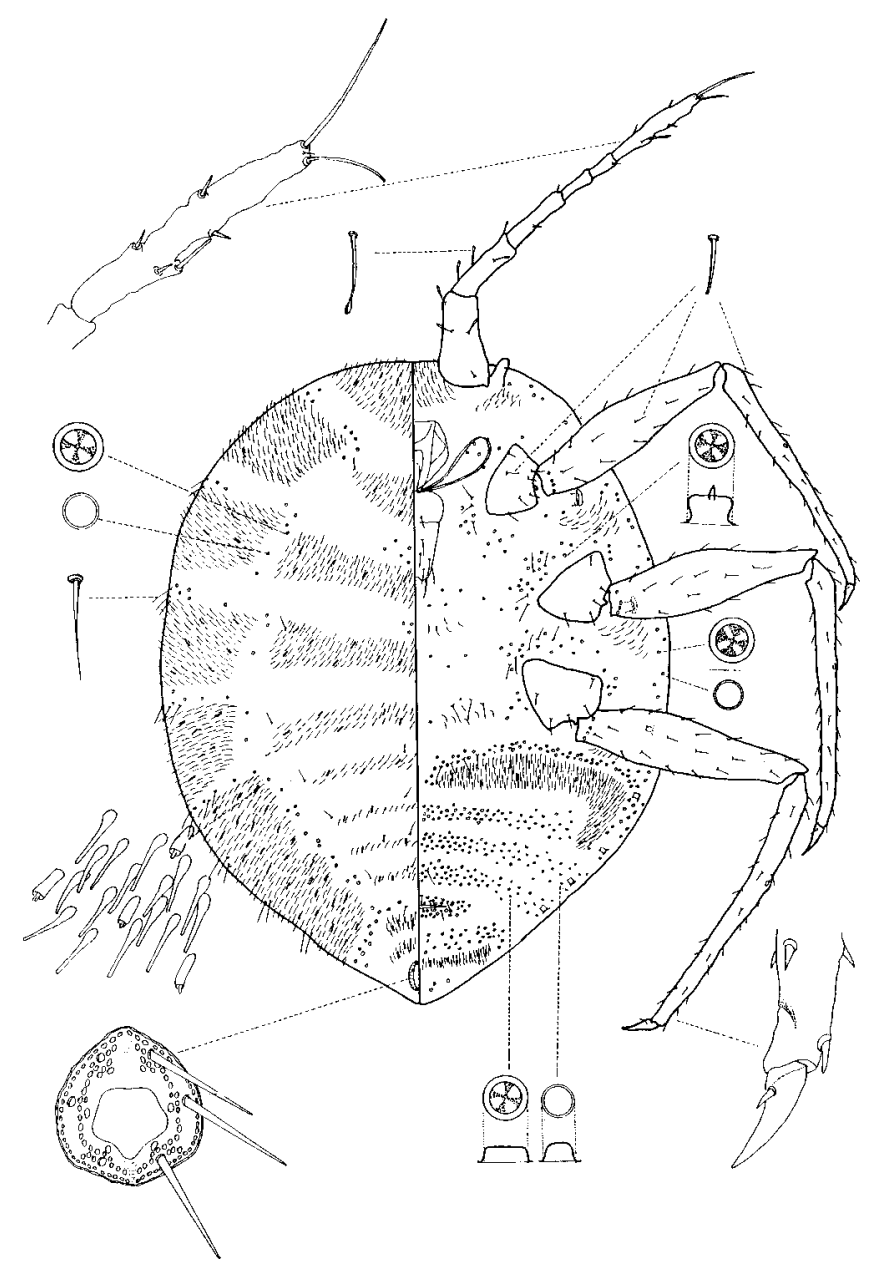

Fig. 9. N. tropicalis sp. n., female

\section{DESCRIPTION OF ADULT FEMALE}

Mounted specimen (Fig. 9): Holotype adult female $1.1 \mathrm{~mm}$ long, $0.9 \mathrm{~mm}$ wide. Antennae 6-segmented, 1st segment $176 \mu \mathrm{m}$ long, 2nd segment $118 \mu \mathrm{m}$ long, apical segment $182 \mu \mathrm{m}$ long, with clavate setae on first two segments, with 7 spinelike setae on next segments, apical seta $96 \mu \mathrm{m}$ long, subapical seta $38 \mu \mathrm{m}$ long, medial sensory seta $33 \mu \mathrm{m}$.

\section{VENTER}

Labium $160 \mu \mathrm{m}$ long. Stylet loop as long as labium. Legs: 1st coxa $102 \mu \mathrm{m}$ long, trochanter-femur 349, tibia-tarsus $432 \mu \mathrm{m}$ long, claw 38, claw digitules $6 \mu \mathrm{m}$ long, 2nd coxa $115 \mu \mathrm{m}$ long, trochanter-femur 374, tibia-tarsus 467, claw 38, claw digitules $6 \mu \mathrm{m}$ long, 3rd coxa $122 \mu \mathrm{m}$ long, trochanter-femur 398, tibia-tarsus $481 \mu \mathrm{m}$ long, claw 41, claw 
digitules $7 \mu \mathrm{m}$ long, partly with clavate, and partly with spinelike setae; without flagellate sensory setae near tibial sensorium on all legs; trochanter with 4 sensory pores on each surface. Ovisac band interrupted in middle, short, ovisac wax plate groups on last segments of abdomen absent; wax plates in small groups on thorax and head. Coxal depressions not developed. Anterior thoracic spiracles with some associated quadrilocular pores, $4 \mu \mathrm{m}$ in diameter, anterior thoracic spiracles $22 \mu \mathrm{m}$ in diameter. Hairlike setae scattered in medial areas of thorax. Quadrilocular and simple pores 3-5 $\mu \mathrm{m}$ in diameter; tubular quadrilocular pores long, protruding from derm, associated with wax plates; quadriloculars and simple pores present in wide, bands within ovisac band and scattered between wax plates elsewhere. Abdominal spiracles five pairs.

DORSUM

Wax plates forming bands on surface. Spines at margin of wax plate elongate, 16 $\mu \mathrm{m}$ long. Hairlike setae present in marginal clusters near posterior edges of marginal wax plates, and near anterolateral and anteromedial edge of each dorsomedial wax plate, 24 $\mu \mathrm{m}$ long. Tubular quadrilocular pores scattered between wax plates, long tubular ducts 16 $\mu \mathrm{m}$ long. Anal ring with two rows of pores; longest anal ring seta $36 \mu \mathrm{m}$ long, anal ring round $48 \mu \mathrm{m}$ in diameter.

The species is named after the tropical region where it was collected.

\section{COMMENTS}

$N$. tropicalis is similar to $N$. brasiliensis, but differs by having clavate setae on the first segments of the antennae, and by presence of long tubular ducts.

\section{Key to adult females of Newsteadia found in these regions}

1. Antennae three segmented

- Antennae more than three segments $\quad 6$

2. Antennal setae clavate

- All antennal setae apically acute

3. All antennal setae long, clavate

borhidii sp. $\mathrm{n}$.

- Antennal seta clavate only on the first and second segment

tristani (Silvestri, 1924)

4. All antennal setae long, hairlike morrisoni sp. n.

- Some antennal seta spinelike

5. With long tubular ducts, without clusters of quadrilocular pores, subapical seta absent trisegmentalis Howell, 1975

- With short tubular ducts, with clusters of quadrilocular pores, subapical seta present costaricaensis $\mathrm{sp} . \mathrm{n}$.

6. Ovisac band interrupted

- Ovisac band not interrupted

7. Tubular ducts short

- Tubular ducts long

floridensis sp. n. 
8. Wax plates densely cover of the venter the thorax, wax plate bands on dorsum not interrupted americana Morrison, 1925

- Wax plates not cover of the venter the thorax, wax plate bands on dorsum interrupted minima Morrison, 1952

9 Part of setae on antennae clavate, with long tubular ducts tropicalis $\mathrm{sp} . \mathrm{n}$.

- Setae on the antenna strong, setose hairlike, with short tubular ducts

brasiliensis $\mathrm{sp} . \mathrm{n}$.

\section{Zoogeographic Considerations}

With the data presented here, and considering earlier reports, the species number of Newsteadia in the Nearctic and Neotropic Regions has increased to 10. Two species (N. americana, N. floridensis, and N. minima) are distributed only in the Nearctic Region,

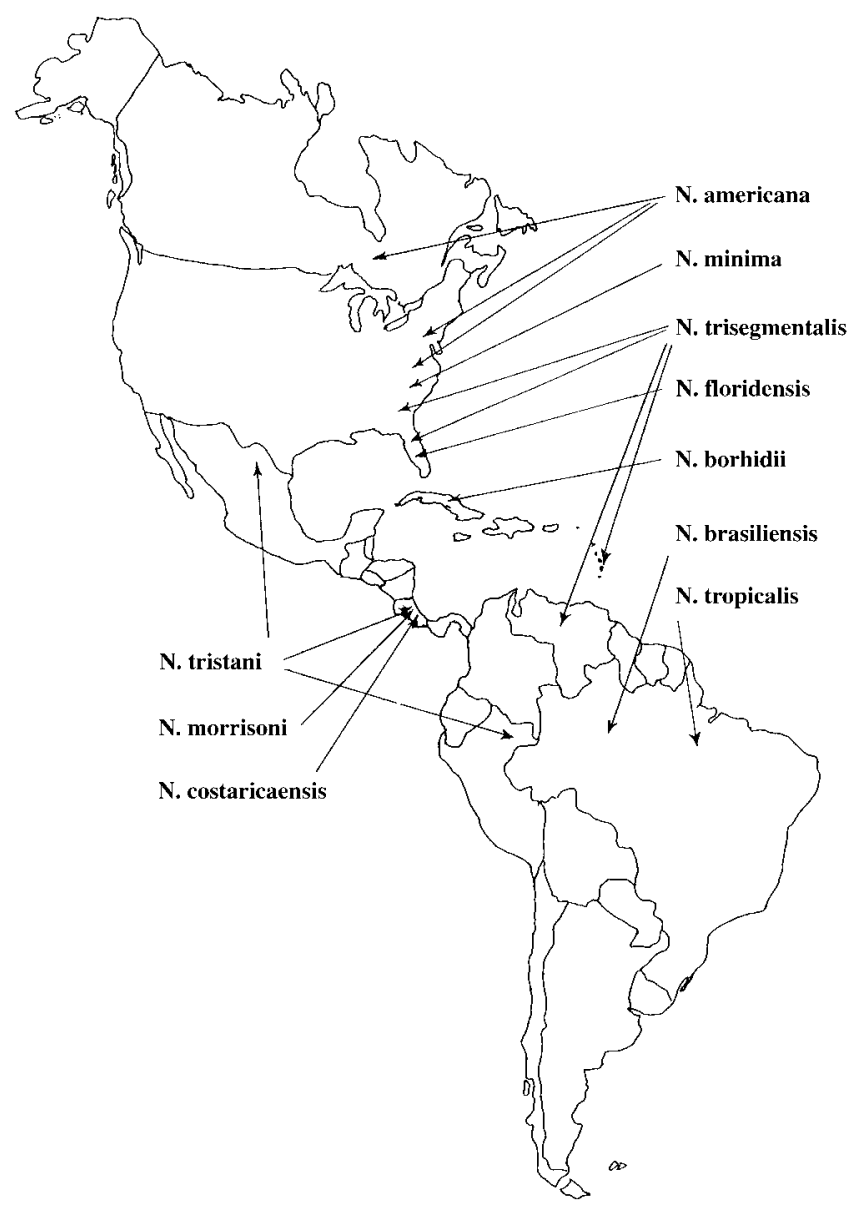

Fig. 10. Distribution of the Newsteadia species in the Nearctic and Neotropic Regions 
six others (N. costaricaensis, $N$. morrisoni, $N$. borhidii, $N$. brasiliensis, $N$. tristani and $N$. tropicalis) are only in the Neotropic Region and one species is (N. trisegmentalis) in both regions.

In the Nearctic and Neotropic Regions most of the species (6) were found in Central America and the northern parts of South America (Fig. 10). N. trisegmentalis has the widest distribution, and presents a link between North, Central and South America on eastern side of the continent through the Caribbean Islands. $N$. tristani presents a link between North, Central and South America on the western side of the continent. $N$. americana is distributed widely in the north-eastern part of North America.

With the new species added to the World list, the total number of the extant species has increased to 37, with two fossil species making the number 39. A worldwide zoogeographical analysis will be undertaken in the future, when treatments of Newsteadia from Australian and Pacific, Oriental and Palaearctic Regions (Kozár and Konczné Benedicty, 1999a, b), and Ethiopian Region (Miller and Kozár, 1999, in preparation) are published.

\section{Acknowledgements}

The authors would like to thank the OTKA (Hungarian National Science Found) (Nos. T 022005 and 025796) for financial support of this project, and especially to Dr. János Balogh (Loránd Eötvös University, Budapest), Dr. Sándor Mahunka (Hungarian Natural History Museum, Budapest), who made his material in his Collection of Arachnida available for us to study. Thanks also to Dr. D. R. Miller for the loan of Newsteadia materials from USDA scale insect collection and for the scientific and English corrections. We are very grateful to Dr. Salvatore Marotta for loan of the original material from the Silvestri collection.

\section{Literature}

Gill, R. J. (1993): The scale insects of California. Part 2, The minor families (Homoptera: Coccoidea). California Department of Food and Agriculture, Technical Series in Agricultural Biosystematics and Plant Pathology 2, 1-241.

Howell, J. O. (1975): Newsteadia trisegmentalis (Homoptera: Coccoidea: Ortheziidae): A new species of scale insect from Georgia. Ann. Entom. Soc. America 68, 163-166.

Kosztarab, M. (1996): Scale insects of Northeastern North America. Virginia Museum of Natural History, Martinsville, $650 \mathrm{pp}$.

Kozár, F. (1988): Catalogue of Palaeartic Coccoidea. Plant Protection Institute, Hungarian Academy of Sciences, Budapest, Hungary, 526 pp.

Kozár, F. and Konczné Benedicty, Z. (1999a): Newsteadia (Homoptera: Coccoidea) of Australian and Pacific Regions with descriptions of new species. Acta Zool. Hungarica 1-12 (in press).

Kozár, F. and Konczné Benedicty, Z. (1999b): Revision of Newsteadia (Homoptera: Coccoidea) of Oriental and Palaearctic Regions, with description of new species. Folia Entomologica Hungarica 60, 165-178.

Miller, D. R. and Kozár, F.: Revision of Newsteadia of Africa (in preparation).

Miller, D. R., Ben-Dov Y. and Gibbson, G.: ScaleNET a searchable information system on scale insects. Entomologica, Bari (in press).

Morrison, H. (1925): Classification of scale insects of the subfamily Ortheziinae. Journal of Agricultural Research 30, 97-154.

Morrison, H. (1952): Classification of the Ortheziidae. Supplement to Classification of scale insects of the subfamily Ortheziinae. United States Department of Agriculture, Technical Bulletin 1052, 1-80.

Acta Phytopathologica et Entomologica Hungarica 36, 2001 